\title{
COMMENTARY
}

\section{THE UNCERTAIN FUTURE OF INTERNATIONAL INDIGENOUS COOPERATION}

\author{
Peter Jull
}

\section{Introduction}

Genuine indigenous internationalism in the 'first world' is now more than 20 years old. At the beginning it was full of zeal and excitement. It had agreed agendas and very few resources. It seemed quixotic to outsiders, but a sense of purpose and of strong shared grievances carried it through the difficult years. It won astonishing victories and had enormous impact on non-indigenous majorities in some countries.

Today budgets are better, travel opportunities are many, new technology makes communication easy and instant, agendas are often so complex or clever that only their authors understand them, and governmental recognition is considerable, if superficial - but the force of indigenous agreement has sometimes been lost. Indigenous internationalism became too successful too soon. One can now see that some of its success came from novelty alone, while it is also clear that many of its early luminaries were domestic players acting briefly on an international stage rather than persons especially attuned or committed to international work. Like all international work, what is more, superficiality and bedazzled participants constantly threaten to take over.

Of course, these generalisations apply to the limited world of cooperation of indigenous political organisations. Does it matter that purposeful political work has stalled and failed to achieve what it first promised? After all, a growing number of informal and individual contacts, or organised contacts outside political networks such as school visits, have become more significant in their total impact. What has political cooperation achieved? What are the present position and future of political cooperation? What could or should it now achieve in a world growing more comfortably international in fact?

\section{Australian Renaissance?}

Two recent Australian reports by the national ombudsman for indigenous peoples, Mick Dodson, may be useful in summing up and clarifying the purpose of indigenous internationalism. ${ }^{1}$ This material intended for Australian policy-making may be as important for indigenous organisations in the Northern Hemisphere. Indeed, this is not the only subject area where a new wave of Australian individuals and organisations are surveying the experience of others. With a critical eye and using insights gained, they are accelerating their continent's catch-up process in indigenous policy while providing, also, a new comparative literature which may be more widely useful in the world. While earlier mainstream official, academic, and indigenous opinion has usually failed to get beyond the uniqueness or special circumstances of Australian experience - the main reason why the

Peter Jull lives in Brisbane. He is a member of the Advisory Broad of the International Working Group for Indigenous Affairs, Copenhagen; an Associate of the Australian National University North Australia Research Unit (NARU), Darwin; and a consultant to indigenous organisations in Australia and overseas.

1

Dodson 1995a:203-219; $1995 \mathrm{~b}$. 


\section{ABORIGINAL HISTORY 1995 19:2}

country has been a late starter in the renewal of indigenous-majority relations - some indigenous leaders and non-indigenous internationalists are now reaching out from their own experience for overseas inspiration. Many of these persons are already well-established in their work, what is more, demonstrating a new maturity within Australia rather than the mere search for novelty by the young. The Australians are 'going international' for solid practical reasons, unlike the first generation of modern internationalists in the Northern hemisphere who had stars in their eyes. For instance, regional agreements have now become one of the biggest items on the Australian political and policy agenda thanks to examination of Canada's experience with hinterland land claims resolution by Donna Craig and a handful of others. ${ }^{2}$ There may be a wider lesson in this sort of focused international work.

In both reports Dodson urges more than occasional fancy-dress internationalism:

Internationalism is something to be practised 365 days of the year. It provides a frame of reference, a way of thinking and a method of work, one by which we are able to see the shared elements of a universal struggle by peoples whose lands have been invaded and lives distorted by colonisers. ${ }^{3}$

He quotes Rigoberta Menchu, the Mayan Nobel Peace Prize winner and now world ambassador for indigenous internationalism, as saying that 'we as indigenous have no borders'. ${ }^{4}$ In his later report he offers a sketch of the origins of modern indigenous internationalism, noting the Arctic Peoples Conference of 1973, foundation of the World Council of Indigenous Peoples in 1975, and of the Inuit Circumpolar Conference in 1977, and the flowering of indigenous internationalism in the most frigid zone of the Cold War with the Circumpolar movement of peoples and governments. ${ }^{5}$ His aim is clear:

International contact is perhaps the most under-used of the major resources of Indigenous peoples in the world today. ... The pressing priority is to gather inspiration, information, and precedents from overseas experience to help develop negotiating positions, options, and policy in Australia. ${ }^{6}$

Not surprisingly both reports stress the importance of comparative studies, and the second includes a background paper on the subject. ${ }^{7}$ He recommends creation of 'an internationalist think tank ${ }^{*}$ and goes on to say that

What is needed is immediate material with practical political and public policy focus.

This should be made widely available to Indigenous organisations, libraries and governments. ${ }^{8}$

Furthermore,

There are some studies which need to be undertaken urgently and their results published. For instance, the concerns expressed by politicians of all parties for Aboriginal and Torres Strait Islander health and community conditions encourage us to look at Norway. Since World War II the Norwegian government has brought all Northerners, including impoverished Sami settlements, a level of public services and

2 Richardson, Craig and Boer 1994; 1995.

3 Dodson 1995a:214.

4 Ibid.:215.

5 Dodson 1995b:42-43.

6 Ibid.:44.

7 Dodson 1995b vol. 3:123-129.

8 Dodson 1995b: 45. 


\section{INTERNATIONAL INDIGENOUS COOPERATION}

personal conditions on its isolated and mountainous Arctic coast equal to the best in the world.

Another example concerns Indigenous coastal and sea matters. In the past two years Torres Strait Islander leaders have forged links with Canadian and Greenland Inuit, Norwegian Sami and Pacific Island nation leaders and found much common interest in marine and sea resource management issues. The Torres Strait Marine Strategy has attracted considerable interest in other countries. ${ }^{9}$

This need for indigenous marine work becomes a specific recommendation, No. 3:

A workshop on Indigenous marine policy issues and needs bringing Torres Strait Islander and Aboriginal representatives together with such overseas peoples as Coastal Sami, Inuit, and Indian First Nations of Canada's Pacific coast, and South Pacific peoples, should be held. The workshop would also consider the usefulness and feasibility of an ongoing international Indigenous marine network of peoples and organisations. 10

The marine item is a particularly good example. Torres Strait Islanders, Canadian Inuit, and Coastal Sami share many social and political realities as peoples less well known in their own countries than Aborigines, Status Indians, or Reindeer Sami, and less defined, officially recognised, or regulated than those peoples. The Torres Strait initiative for a Marine Strategy was in part inspired by Canadian Inuit-government cooperation, while its development has interested overseas indigenous peoples and experts, e.g., Inuit Canada, Sami Norway, and the South Pacific, and fed back into their work and indigenous processes in their home countries. ${ }^{11}$ This Torres Strait work, with all its overseas connections, proved important in Australia's national policy development process which was proceeding at the same time. ${ }^{12}$ All the while in world forums Australian environmental internationalists were involved in promulgating agreements and guidelines for fisheries and traditional inhabitants in coastal areas. Torres Strait itself is largely subject to the terms of a unique Treaty between Australia and Papua New Guinea involving constant multi-partite dialogue and dispute. The Islanders' present marine coordinator came to her work from hands-on work of a similar kind in the Solomon Islands. In other words, conditions are ideal for international work on marine issues involving Torres Strait.

However, while Dodson was completing his report the leader of the Senate opposition party, Australian Democrats, posed for the media on a Sydney beach beside 100 different coastal reports urging Australian coastal management measures: her point was that there had been little action on their recommendations. Furthermore, all the footnotes to overseas parallels count for nothing unless a sense of practical purpose is instilled, and active and ongoing cooperation takes place. This requires initiative, confidence, savoir faire (or just plain savvy), and some degree of organisation and funds. Postage or e-mail will do, but someone must actually put the materials in an envelope or type in the message. It is at this point that marine cooperation - and most other ideas for international work - break down.

Dodson's Australian reports provide a useful update on needs and possibilities. These must now be translated into action. At the time of writing it is too early to know if this will happen.

9 Ibid.:46.

10 Ibid.:48.

11 Cordell 1991; Lui 1994; Mulrennan 1994; Mulrennan and Hansen 1994.

12 RAC 1993; Smyth 1993; Jull 1993. 


\section{The Circumpolar Movement}

Like Dodson we may turn to the Circumpolar movement for some idea of what can happen when indigenous internationalism is successful. The subject can be considered on four levels: local/regional, national, Circumpolar, and broader international. The Canadian case will be used here, ${ }^{13}$ but it must be remembered that Inuit of Greenland, Alaska, and Russia find different meanings and value in indigenous Circumpolar linkages. It used to be said outside the meeting chamber at the week-long 3-yearly Inuit Circumpolar Conference (ICC) assemblies that Greenland Inuit had real political power, Alaskan Inuit had real financial resources (though this is not equally true of all Alaska's Inuit regions), and Canadian Inuit maintained the highest degree of traditional Inuit culture. It is important to note that indigenous internationalism to date has been entirely coloured by local and regional imperatives, and that a real internationalism scarcely exists except among nonindigenous lawyers, resource management researchers, anthropologists or human geographers, and human rights workers. Really international workers among indigenous people themselves are usually involuntary exiles from home, or pressing a home agenda in some international forum.

On the local and regional level, Inuit participation in ICC meant that isolated huntergatherer people and communities who had felt marginalised and disadvantaged in Canada now had the greater resonance of an international culture and the support of active political allies abroad. Every community played and replayed audio tapes and videos from the last ICC assembly week, a week as full of cultural performances and popular Inuit-language pop music as of political discussions. It is ironic that one of the world's most isolated peoples no two Canadian Inuit communities being connected by road - gets more immediate benefit at an individual level from its leaders' international activities than do far more materially developed, educated, and powerful peoples and nation-states.

Also, Inuit leaders and organisation staff working on regional land/sea claims, environmental issues, social issues, and self-government projects have had frequent opportunities to discuss such matters with Inuit from other countries who are fighting or have fought the same battles. They know that however resistant may be the Canadian public and governments to their demands, such things are proceeding elsewhere and that such things are therefore neither impossible nor impractical. When visiting other countries they have the chance to speak about their problems at home to sympathetic audiences, while their gatherings and other projects attract international media attention. The importance of such psychological support cannot be overstated for a people who include almost no university graduates or higher work skills but who are negotiating their survival with a powerful national government.

At the opening of the 1980s the Arctic Pilot Project, a scheme to bring liquefied natural gas south by tanker from the Arctic Islands for markets in North America and Europe, saw all of the six Canadian Inuit regions joined by the Inuit of Greenland and North Slope Alaska in opposition. With the help of money and experts from Alaska and Greenland, the Canadian Inuit mustered all their resources to oppose the project in regulatory board hearings. The pilot nature of the project they saw as forerunner to marine oil drilling and shipment, a fear which unites all Inuit (who rely on the sea for their livelihoods and food), and as piloting industry through regulatory, indigenous, and environmental uncertainties. The eventual defeat of the project, by no means due only to indigenous and environmental concerns, seemed a tremendous vindication of Inuit cooperation. The effective Inuit role and their substantive views in the hearings marked a 


\section{INTERNATIONAL INDIGENOUS COOPERATION}

turning point in Canadian government and public infatuation with resource mega-projects in the far North. Of course, Inuit believed they had no choice: the coming of big industry and transport would pre-empt their attempts to get a say in the future of their homeland through eventual regional land/sea claims, national constitutional reform, and regional selfgovernment structures.

At national level, publicity over issues like the Arctic Pilot Project and many others have altered Canadians' view of the North which is, after all, the fundamental myth of Canada since European settlement. ${ }^{14}$ No longer an empty and forbidding white blur of snow and ice awaiting the transforming genius of white settlers, it came into focus as a place of well demarcated Inuit (and Indian) homelands with rich traditions, art both lively and profound, humour and pathos, intact cultures insisting on their distinct place in Canada even amid the welter of material change, and a social and economic ethic which repudiated facile European notions of industrial and liberal development. No mere isolated romantics, these young Inuit were, and were seen to be, part of a much larger international movement.

Furthermore, the Arctic was no longer an embarrassing backyard about which Canadian governments were coy with foreigners, a place in which one could slowly bring some recalcitrant primitives towards proper civilised life - rather, it was part of an extraordinary East-West region of peoples and homelands who had different ideas about the future and renewed confidence in the very traditions which Canadians had regarded as backward. It was clear that sanctimonious Canadians trying to change these people had been wrong in their assumptions, if not in their earnest goodwill. They had read the North all wrong. The North now made up about $75 \%$ of Canada's land area, i.e., the region beyond the Southern agriculture zone. Its scattered Inuit, Indian, and Métis villagers were now travelling overseas together to fight for their way of life in the fashionable capitals of Europe where gentle bourgeois wanted to end the trapping and hunting which provided their only sure sustenance.

There was also a direct impact on national political life through the constitutional review processes. There the Inuit and other Northern peoples were preaching their new social and cultural ethic via nationally televised conferences during the 1980 s, and again in the 1990s. They advocated collective and cultural rights, and won recognition for preEuropean Canada as a living political community which must be accommodated in any authentic national reform. The resolution of native title claims was, in fact, a grass-roots constitutional revision process which was filling in the map of Canada with new political structures. ${ }^{15}$ Inuit were not coming to national conferences to negotiate the basics but rather to share with others the new Canada they were achieving and ask that these realities be reflected in the national Constitution.

At the Circumpolar level the cooperation among Inuit and between Inuit and other Northern peoples - Sami of Scandinavia, Russian peoples from 1989, and North American Indians - represented more than a thaw in the Cold War which had militarised and immobilised the Arctic. It challenged the notion that the national interest lay merely in rigidly maintaining central control of developments in that region. It now brought decentralist and pluralist values into the equation, and made a mockery of a Northern Development ethic which served the national balance of payments while leaving the permanent Northerners impoverished and risking their main economic asset, i.e., the natural environment. Led by Inuit, Canada saw a thaw in relations among peoples and interest groups at home, and a sense of excitement about the discovery of a new region of the world

14 Jull 1994a:66-76.

15 Jull 1995. 
in which Canada really mattered (thanks to its sheer size no less than its outlook) and where many worthwhile challenges existed. 16

Protection of the environment, especially the marine environment, with its corollary issues of resource and other physical development, became the most obvious area for cooperation. Mary Simon, the ICC president from 1986-1992, made this cause her own and made it also the centrepiece of her work to develop a truly Circumpolar regional structure linking all peoples, national governments, and sub-national Northern governments in the Arctic. A measure of her success is the fact that in 1994 Canada appointed her its first Ambassador for Circumpolar Affairs, a full-time post in the foreign ministry.

The breaking down of national isolation in the Arctic, and redefinition of the region as a place for multilateral cooperation, peace, and goodwill in which the indigenous inhabitants are respected interlocutors and leaders, is an overwhelming achievement. Its impact is being felt in all areas of Northern life and policy. In 1989 at the Sisimiut, Greenland, ICC assembly a succession of ministers and heads of government from national and Northern sub-national USA, USSR, Canada, and Denmark governments lined up in a sort of international accountability session to report on their progress and commitment in implementing ICC policy resolutions. A scattered hunter-gatherer people and their local delegates in the chamber had come a long way in a very few years thanks to international cooperation.

On the wider international level, Inuit alone and with others have taken their own culture and the Arctic from a realm of silly stereotypes and nature documentaries, subjects of curiosity, and made them serious representatives of environmental protection and respect for cultural diversity in world bodies. ICC has been very active in world forums of many types, and ICC events are typically reported by leading world media. What is more, an almost unknown region of the world is now open to world scrutiny and criticism, placing the Circumpolar governments under unprecedented pressure to behave well in the region. Inuit leaders and staff born in isolated snow-houses and tents and brought up with little knowledge of the nearest community beyond their own trading post now find themselves in mid-life talking with world leaders and travelling the world as a sort of global conscience. The view and confidence this brings to Inuit politics and society back home may be guessed.

New threats to their success come from Inuit transition from political associations to governing powers. Governments with complex agendas have little interest in free-lance idealists outside their control. With real power in their home regions, what is more, Inuit leaders are necessarily more occupied with local and regional issues and have less interest or need for wider appeals to higher or wider political authority or the public which supports such authority. ICC may have to trade some of its freedom and enthusiasm for more secure funding by Inuit governments, the alternative being irrelevance or gadfly status. If the most dramatic achievements of ICC as a virtually independent entity are past, there are many important possible roles ahead. What is more, the two-tiered indigenous-government multilateral cooperation structures for the Circumpolar region being pursued by Mary Simon with full official Canadian government support may transform the whole picture. ICC would be a logical inter-Inuit coordination office and secretariat for such work if the jealousy of regional Inuit governments can be overcome.

To conclude this subject, Inuit have won battles with local rednecks, regional development-hungry authorities, national governments, and international interests like the oil majors thanks to international contacts and cooperation. They have redefined large 


\section{DNTERNATIONAL INDIGENOUS COOPERATION}

hinterland regions and whole nation-states as indigenous space or space in which indigenous aspirations are central issues. They have also re-written world standards in the practice of indigenous rights and environmental protection (i.e., their basic economic concern). They have done this with minimal funding, with tiny and sometimes shoe-string operations, and without initial sympathy or support from governments. They have had their share of timeservers and wasted opportunities, but their essential sense of political purpose and shared agendas has seen them through all difficulties.

\section{Sami Rights}

The Sami present a puzzle. Perhaps the most well-educated and work-skilled indigenous people in the first world apart from Maori élites, the Sami have failed to convince Norway, Sweden, and Finland public and governments of the need to recognise their rights. ${ }^{17}$ Each day more of their remaining territory in the North is lost to them through development or regulation - territory which they have indisputably used and occupied since the Ice Age glaciers receded many thousands of years ago. There have been official and other respected studies urging the three governments to recognise Sami rights, to no avail. The famed progressive spirit of the Nordic countries, evident in Denmark's accommodations of Faroese and Greenland ethno-regionalism, has not extended to Northern Scandinavia. Of course, national intellectuals in those countries have long recognised that pluralism is a different challenge from social equity and one which presents great difficulties for their societies. ${ }^{18}$

Why have Sami leaders not pressed hard for Sami rights, especially in Norway where dismissive reports released in $1993 \mathrm{fly}$ in the face of common sense and international experience?. ${ }^{9}$ Various answers have been suggested. Sami leaders are busy professionals in critical periods of mid-career or at the stage where they want a quiet life after long struggle. Sami leaders believe that governments will do the right thing. Sami leaders are now in the pocket of governments. Whatever the reason, three facts are inescapable. (1) No government in history has voluntarily sought out good to do by recognising the territorial rights of indigenous minorities - and it is probably safe to say that none ever will! (2) Sami leaders have been saying for 25 years that they must have land, freshwater, and sea rights. (3) Sami leaders are aware that all indigenous peoples seek land and/or sea rights and that a number of countries with whose indigenous leaders they fraternise have recently won court cases and policy changes on the very grounds upon which the Scandinavian governments base their rejections! (The Scandinavian argument is a slightly dignified terra nullius view.)

Clearly, then, the Sami leaders are unable or unwilling to use the benefit and precedents of others. This is remarkable in countries which are compulsively and habitually internationalist. It has been said that because Sami have had their living conditions improved in recent decades by governmental action, they are reluctant to claim indigenous rights. However, Sami themselves have been vocal for decades in denying that government policies which confer socio-economic benefits are the same as territorial, cultural, or selfgovernment rights. It is very discouraging that an otherwise sophisticated socio-cultural movement is so unsure of itself in major political matters; it is worse that their uncertainty threatens indigenous peoples everywhere. After all, if the most progressive countries can deny the territorial and related rights of indigenous minorities, there is very little incentive for Indonesian or Guatemalan governments to do otherwise.

\footnotetext{
17 Jull 1994b.

18 Dadalus 1984.

19 Brantenberg 1993.
} 
Yet the Sami leadership are active in travel and attendance at functions abroad. They speak well and are multi-lingual to a man or woman. They are fine representatives of a mature indigenous modernity in all but one particular - they have failed to begin talks on, or even to win recognition for, their rights agenda, i.e., on the very thing which identifies them as an indigenous people. Far from being an international model for others, one might like to say, like Byron of a timid people of his time, 'For Greeks a blush - for Greece a tear'.

\section{Discussion}

It seems that the initial impact of indigenous internationalism begun in 1973 with the Arctic Peoples Conference has been spent. That early phase had several features. The sheer novelty of remote hunter-gatherer peoples taking on international roles and speaking to the world about hinterland regions little known even within their own nation-states caught the public and government off guard. Much of the Inuit ability to get Canadians' attention derived from no greater cause.

One may also doubt whether the early impact of indigenous representatives from different countries issuing joint statements on public issues is any longer as great as it once was. Governments initially had to adjust to this new source of political criticism, and in the Northern Hemisphere, at least, have largely done so. In the process, of course, indigenous peoples gained permanent benefits in terms of further influence on and access to policy-makers. For instance, Inuit internationalism is now a permanent factor in Canada's Arctic environmental work, and a much more substantial one than Torres Strait Islanders in the Torres Strait Treaty processes in Australia.

The indigenous persons who founded indigenous internationalism were young leaders at home no less than internationally. The more demanding home arena and the greater certainty of funding at domestic level have taken most of their time. For leaders as individuals, the passage of time, and the loss of novelty have often tumed extroverted youth burning with activist purpose into comfortable middle-aged tourists.

As in domestic aspects of indigenous politics, the initial need for advocacy, attentiongetting, and agenda-setting skills has given way to a politics in which more negotiation and work skills are needed to make real progress. Not all individuals or organisations have had the qualifications or patience to make that transition. The same problem has been a major stumbling-block for indigenous politics at home, e.g., within Canada. However unfashionable it may be to say so, a good part of the various failures in indigenous Canada in the past 15 years are due to indigenous groups being unwilling or unable to sit down and work through issues they themselves had raised when governments finally agree to negotiate solutions nor is all of this due to insufficient funding for indigenous preparation.

If some of the Northern Hemisphere indigenous internationalists have lost their way, or been seduced from their activist earlier agendas by the comforts of government-funded international travel, the Australian initiative of Mick Dodson may be a timely corrective. Not only does he endorse and sum up the genuine magnificence of the Northern Hemisphere peoples' international achievements, but he proposes practical ways to build on them. He also focusses his proposals on practical and issue-oriented work. Australia is now ready for the next generation of indigenous internationalism. Within ICC, too, it has been from the Russian side - the newcomers to the organisation - that most awareness of the scope for practical work has come. ${ }^{20}$ 


\section{INTERNATIONAL INDIGENOUS COOPERATION}

A guide for conduct in indigenous internationalism for voluntary use is badly needed. Much international indigenous contact is irresponsible, and most contact is productive of little more than the personal experience of individuals participating.

It is common for indigenous representatives to travel overseas and, like missionaries of old, co-opt foreigners into their feuds with other indigenous groups at home. In Australia, for instance, it is common for Canadian Indian speakers to misrepresent and disdain Inuit projects such as Nunavut. ${ }^{21}$ The problem with this is that the information offered about Nunavut by such speakers is almost always wrong, and the listeners would usually find both Canadian Indian and Inuit progress with claims settlement and self-government of value because it is more advanced than their own. Also overlooked is the fact that all indigenous peoples are seeking the same things: recognition of collective rights (including rights to sea and land territories), more or less autonomy within existing nation-states, protection of traditional livelihoods and the environments which provide the base for those, cultural maintenance and enhancement, and powers of political decision-making. Different peoples, or different groups of the same people, may choose different approaches for various practical reasons, but there are important lessons for others in those choices.

As peoples who have suffered so much from the ethno-centricity of majority societies, indigenous peoples should be especially anxious to avoid chauvinism and insensitivity towards each other. Another form of this same problem is the enthusiasm with which some leaders rush to patronise others they deem more unfortunate then their own people. The proper relationship towards other indigenous peoples is respectful listening. However selfsatisfied some indigenous leaders may be, nowhere more than in Scandinavia or parts of the Great Plains of North America, all have a great deal to learn and to understand before they are on an equal political footing with national governments. Admittance to an official dinner with king, president, or prime minister, and ability to articulate a position decorously in a formal setting, mean nothing.

No less important than a willing suspension of disbelief towards the political experience of others is good use of the opportunities available to oneself. Many of today's indigenous leaders remember well the recent times when overseas travel was unthinkable, and, when the chance came, a major personal experience. Today indigenous representatives spend many bored hours between duty-free shops in the air and in airports, and are as familiar with the ways of fine hotels and foreign dining as the pick of their home nation's Clite. Too often they fail to use their contacts to gather documentary information or make notes on precedents; when they recover from jet-lag and cross-cultural daze back at home they have nothing but a few impressions.

Equally, they must become open to what they find. Many Canadian Inuit politicians dismissed Greenland's experience for years despite visits there because they had heard one or two of the young Greenlanders dismiss it as an empty deception by Danes. The fact is that from virtually any point of view, Greenland Inuit home rule is the standard-bearer of indigenous self-determination. The Canadian Inuit, who were trying to negotiate both land claims and regional self-government at the time, could have learned a great deal of immediate use to them. Various Canadian Indian groups who had none of the advantages of first-hand contact or a shared Inuit language were wiser and learned all they could from written accounts of Greenland's emerging nationhood.

If a few indigenous organisations would take the initiative to draw up, circulate, improve, and propose voluntary adoption or guidelines for indigenous internationalism, such work would be more prolific, more useful, and less conducive to mischief and ill-will.

21 Jull 1994c. 
One small step in this direction is provided by a 13-point list in the Inuit Circumpolar Conference Arctic Policy, 'Principles and Elements on Circumpolar Regional Cooperation'.22

As for larger questions of indigenous multilateralism, the essential divide may be between governments and proto- or quasi-governing authorities on the one hand, and NGOs (non-government organisations) on the other. Peoples fighting for rights against great odds, and with little to lose, are in a different category than recognised authorities who have complex agendas and sensitivities to manage. For instance, the fact that the Inuit Circumpolar Conference has been made up from the beginning of peoples with the reality or not too distant hope of managing their homelands in law may have fashioned the ICC tone no less than has the notoriously pragmatic Inuit culture. The different needs and interests of each category - recognised authority and NGO - should be recognised at the outset to prevent frustration or embarrassment and ultimate withdrawal from international forums by different peoples.

Although international awareness is growing among indigenous peoples everywhere, as well as individual travel and group exchanges, this has little impact on politics. Political work requires specific and focussed attention and conduct; it cannot be taken for granted. It is not sufficient for us to predict comfortably that in 25 years all indigenous peoples will be proud of sharing a common agenda if in the meantime their lands and seas are lost and they become a desperate rustic proletariat living in the packing crates left by oil companies and military forces and gathering food in the White Man's garbage dumps.

Already indigenous peoples have been widely recognised as having a special role to play in the philosophy and politics of environmental protection world-wide and this could become an organising principle for formal indigenous multilateralism. Much wider functions could flow from that, just as 'first world' nations have been taught by Aborigines and Islanders and other peoples that the land and sea are their first and best principles. The fact that the world understands environment as an issue, however lacking in will to act upon it, and that it is the easiest way for indigenous people to show their relationship to land and sea territories and their need for secure rights in relation to these, makes environment this the most obvious area for intensification of indigenous international work. Even social justice is not such a good bet in the long-term because societies will surely soon be levelling down, not up, and imposing harsh measures on all citizens during world crises of many sorts. Land and sea territory will better sustain indigenous peoples, as they have always done.

\section{Conclusions}

International cooperation by indigenous peoples began as an attempt to press governments at home to recognise indigenous rights, as a sharing of experience with other peoples in order to raise international standards for recognition of such rights, and as a way of leaming from others' experience in order to grasp better the political options available and probable majority responses at home. In many cases today that work has become a means for governments to use indigenous leaders to justify national policies abroad, and, for indigenous leaders to patronise others by intlating home experience while rejecting the experience of others as of no relevance. Sadly, this change has often occurred wihout indigenous peoples achieving the basic goals for which their international cooperation was first begun. Sophistication in international matters comes not from staying at fine totels or giving pretty replies when official gifts or welcomes are given, but from gaining

22 ICC 1992:28-30. 
knowledge, insight, and allies. The political power relations between indigenous peoples and newcomers in their territories are everywhere the same. If Manhattan was traded for \$24 worth of trinkets and cloth in 1626, the virtual handover of sea, land, and resource rights today in sweeping hinterlands across countries and continents for a few indigenous plane fares and invitations to official dinners is no less outrageous. Nor did the Indians of Manhattan become apologists for their dispossessors in the United Nations or in world news interviews.

Indigenous rights and international politics are not about social status. They are about the power to govern territory and the economic benefits from the exploitation of territory. All the rest is flim-flam and public relations - a certain amount of which is inevitable in political life, but not to be confused with political substance. Role models and individual success stories are all very nice, but they do little more than confirm or justify existing inequalities. They may sometimes symbolise real change or be its heralds, but they do not cause change. On the other hand, individuals representing real political power are rarely barred from the company of ministers or prime ministers, queens or kings, on account of their manners or morals.

Indigenous internationalism in 'first world' countries has so entirely lost its way - that is, become so distracted from its real value, purposes, and functions - that it must be virtually re-invented from the ground up. It has an important, even urgent, role in the immediate future of indigenous peoples: to enable them to secure legal and political rights as unique communities before they are finally alienated from their territorial and resource base (or before that is so poisoned as to be as good as gone). Generalised international niceness and fortuitous personal contacts abroad cannot make up for a lack of focussed political work. New technologies and other developments provide major advantages unavailable to the first generation of modern indigenous internationalists. The outline of a practical internationalism offered by Australia's indigenous peoples' ombudsman, Mick Dodson, may be a useful starting point. The task is really very easy, but someone must begin it.

\section{LIST OF REFERENCES}

Brantenberg O.T. The end of 13 Years of Silence: The Sami Land Rights Issue in Norway, IWGIA Newsletter, No. 4/1993 (October-December), International Working Group on Indigenous Affairs, Copenhagen, 26-40, 1993.

Canadian Arctic Resources Committee (CARC). 'Seminar 4: Canada's Interests in the International Arctic', Changing Times, Challenging Agendas: Economic and Political Issues in Canada's North, Canadian Arctic Resources Committee, Ottawa, 109-159, 1988.

Cordell J. Managing Sea Country: tenure and sustainability of Aboriginal and Torres Strait Islander marine resources, ESD [Ecologically Sustainable Development] Secretariat, Commonwealth Government, Canberra, 1991.

Dedalus. The Nordic Enigma, being Dadalus, Journal of the American Academy of Arts and Sciences, Vol. 113, No. 1, Winter 1984.

Dabl J. Indigenous Peoples of the Arctic, Nordic Council, Copenbagen, 1993.

Dodson M. Second Report, 1994, Aboriginal and Torres Strait Islander Social Justice Commissioner, Human Rights and Equal Opportunity Commission, Australian Government Publishing Services, Canberra, 1995a.

. Indigenous Social Justice, Volume 1: Strategies and Recommendations, Submission to the Parliament of the Commonwealth of Australia on the Social Justice Package by Michael Dodson, Aboriginal and Torres Strait Islander Social Justice Commissioner, Human Rights and Equal Opportunity Commission, Canberra. (Accompanying background material as Volume 2: Regional Agreements, \& Volume 3: Resource Materials.), $1995 \mathrm{~b}$. 


\section{ABORIGINAL HISTORY 1995 19:2}

Inuit Circumpolar Conference (ICC). One Arctic, One Future, Proceedings of the Inuit Circumpolar Conference Sixth General Assembly, Inuvik, NWT, Canada, 1992a. - Principles and Elements for a Comprehensive Arctic Policy, Inuit Circumpolar Conference with the Centre for Northern Studies and Research, McGill University, Montreal, 1992b.

Jull P. and Roberts S. (eds) The Challenge of Northern Regions, Australian National University North Australia Research Unit, Darwin, 1991.

Jull P. Politics, Development and Conservation in the International North, Canadian Arctic Resources Committee, Ottawa, 1986.

The Politics of Northern Frontiers, North Australia Research Unit, Australian National University, Darwin, 1991.

- A Sea Change: Indigenous-Government Relations in the Coastal Zone, Resource Assessment Commission, Commonwealth of Australia, Canberra, September 1993.

. Inventing and Re-Inventing the North in Canada: Inuit-European Relations, 1000-2001

$A D$, Working Paper for the Canadian Office, Inuit Circumpolar Conference, Ottawa, March, $1994 \mathrm{a}$.

. A Thousand Years: Indigenous Peoples and Northern Europeans, 2nd ed (Completely revised and expanded), An Essay Commissioned by the Royal Commission on Aboriginal Peoples, Ottawa, October 15, 1994b.

Them Eskimo Mob: International Implications of Nunavut, Revised 2nd. edition, An Essay Commissioned by the Royal Commission on Aboriginal Peoples, Ottawa, September 30, 1994c.

Re-Inventing Canada: The North and National Policy, Revised 3rd Edition, [Earlier version titled The North and National Policy], An Essay Commissioned by the Royal Commission on Aboriginal Peoples, Ottawa, February 7, 1995.

Jull P., M. Mulrennan, M. Sullivan, G. Crough, and D. Lea (eds). Surviving Columbus: Indigenous Peoples, political Reform and Environmental Management in North Australia, Australian National University North Australia Research Unit, Darwin, 1994.

Lui G. 'A Torres Strait perspective', in Voices from the Land: 1993 Boyer Lectures, Australian Broadcasting Corporation, Sydney, 62-75, 1994.

Minority Rights Group (MRG). Polar Peoples: Self-determination and Development, edited by Minority Rights Group, Minority Rights Publications, London, 1994.

Mulrennan, M. and N. Hanssen, (eds). Marine Strategy for Torres Strait: Policy Directions, Australian National University North Australia Research Unit, Darwin, and Island Coordinating Council, Torres Strait, 1994.

Mulrennan M (ed). 'The Marine Workshop', in Jull et al. 1994, 38-86, 1994.

Osherenko G. and O.R. Young. The Age of the Arctic: Hot Conflicts and Cold Realities, Cambridge University Press, Cambridge, 1989.

Resource Assessment Commission (RAC). 'The Role of Indigenous People', Coastal Zone Inquiry: Final Report, Resource Assessment Commission, Commonwealth of Australia, Australian Government Publishing Service, Canberra, 165-189, 1993.

Richardson B.J., D. Craig, and B. Boer. Indigenous Peoples and Environmental Management: A Review of Canadian Regional Agreements and Their Potential Application to Australia - Part 1', Environmental and Planning Law Journal, Vol. 11, No. 4, August 1994, 320-343; \& 'Part 2', Vol. 11, No. 5, October 1994, 357-381.

. Regional agreements for indigenous lands and cultures in Canada, A Discussion Paper, Australian National University North Australia Research Unit, Darwin, 1995.

Smyth D. A Voice In All Places: Aboriginal and Torres Strait Islander Interests in Australia's Coastal Zone (Revised Edition), Resource Assessment Commission, Canberra, 1993. 